\title{
Dissipation of Electrical Energy into Heat Energy in Web-Based Rainfall Meter Microcontrollers
}

\author{
Sensus Wijonarko ${ }^{1 *}$, Aditia Warman ${ }^{2}$, and Ayub Kurnia Sitorus ${ }^{2}$ \\ ${ }^{1}$ Physics Research Centre - Lembaga Ilmu Pengetahuan Indonesia (LIPI), Kompleks Puspitek Gedung \\ 442 Serpong Tangerang Selatan Banten 15314, Indonesia \\ ${ }^{2}$ Department of Physics, Faculty of Mathematics and Natural Science, Universitas Sumatera Utara, \\ Medan 20155, Indonesia.
}

\begin{abstract}
The heat dissipation of a system has been observed. In this study, the Arduino Nano as a microcontroller of web based rainfall gauge calibrator will be analyzed through the application of an automatic pump, the DHT22 sensor as a detector for temperature change on the microcontroller on standby for 5 minutes and operate for 55 minutes. Electrical energy can be obtained from voltage and current measurements using a multimeter and heat energy can be obtained from temperature changes detected by the DHT 22 sensor. The temperature sensor readings are displayed from the microcontroller to the PC into the PLX-DAQ application as an interface. From the results of observations and calculations, the data obtained on the percentage of electrical energy dissipation into heat energy has 4 stages, that is on standby $8.9 \%$, from the end of standby to operate at $1.0 \%$, transition $0.2 \%$, and ideal stable $0.1 \%-0 \%$. After 20 minutes until finished operating shows an ideal stable state. This is due to the microcontroller heat dissipation and energy absorbed by the ambient is the same.
\end{abstract}

Keyword: dissipation, electrical energy, heat energy, microcontroller, PLX-DAQ

Received 5 February 2021 | Revised [19 February 2021] | Accepted [25 February 2021]

\section{Introduction}

Global warming occurs as the Earth's surface temperature continues to rise, quoted from NASA's Goddard Institue for Space Studies (GISS), where the Earth's temperature had risen by nearly $1^{\circ} \mathrm{C}$ in 1880 . This increase will continue until it reaches more than $2^{\circ} \mathrm{C}$ by 2030 [1]. The causative factor of global warming is the inefficient use of electrical energy [2]. Inefficient use of electrical energy will result in energy dissipation [3]. Energy dissipation is the wasted energy of a system. Any energy that is not transferred to energy storage will be wasted into the environment. Energy wasted in a system often occurs in the form of heat. Heat energy wasted into the atmosphere will be the cause of global warming [4]. Technological developments have brought tremendous benefits to facilitate human activity. One form of development of this

*Corresponding author at: Kompleks Puspitek Gedung 442 Serpong Tangerang Selatan Banten 15314, Indonesia

E-mail address: sensusw@kim.lipi.go.id 
technology is the use of microcontrollers. Microcontroller is a chip that looks like an IC (Integrated Circuit) [5].

The use of microcontrollers is increasingly evenly distributed in all areas, one of which is calibration. Calibration is a process to compare measuring instruments with their standards with various methods at national and international standards [6]. Calibration is performed on various measuring instruments such as rainfall gauges. Rainfall gauges are important in calibration at least twice a year. Until now there are four types of calibration methods of rainfall gauges used to calibrate rainfall gauges, namely The Static calibration method, The Dynamic calibration method by Calder and Kidd (1978), The Automated Dynamic Calibration method by Humphrey and Istok (1997), and The web based calibration method by Wijonarko et al. (2017) [7]. A webbased rain gauge calibrator is a tool to calibrate rain gauges whose results can be downloaded from the web. This calibrator uses a microcontroller as a control system in its calibration process. In this study will be done measurement of changes in temperature, voltage, and current in microcontroller at standby and operate by using sensors that serve to convert physical magnitude into proposional electricity [8] with DHT22 sensor type and multimeter through relay program as switch on automatic pump. The pump moves the fluid due to pressure differences. [9] Therefore, this measurement is carried out to analyze the dissipation of electrical energy into heat energy in the controlling system used by web-based rainfall callbrators.

\section{Methods}

The system block diagram shown in Figure 1 consists of 2 systems that have inputs. The first system input is DHT22 sensor as temperature change detector in the form of digital signal [10] microcontroller and the second system input is relay as controller ON/OFF [11] peristaltic pump and load for microcontroller to be tested. The part that processes sensor data and relay work is Arduino Nano by micro USB programming [12]. DHT22 sensor will be read, calibrated, and converted into temperature value with Celsius unit [13]. Relay will work connecting the power source to the peristaltic pump. Peristaltic pumps can pump fluid in any direction by changing the direction of the roller rotation [14]. The resulting data of the received temperature change will be displayed automatically into Microsoft excel in real time with PLX DAQ application [15]. 


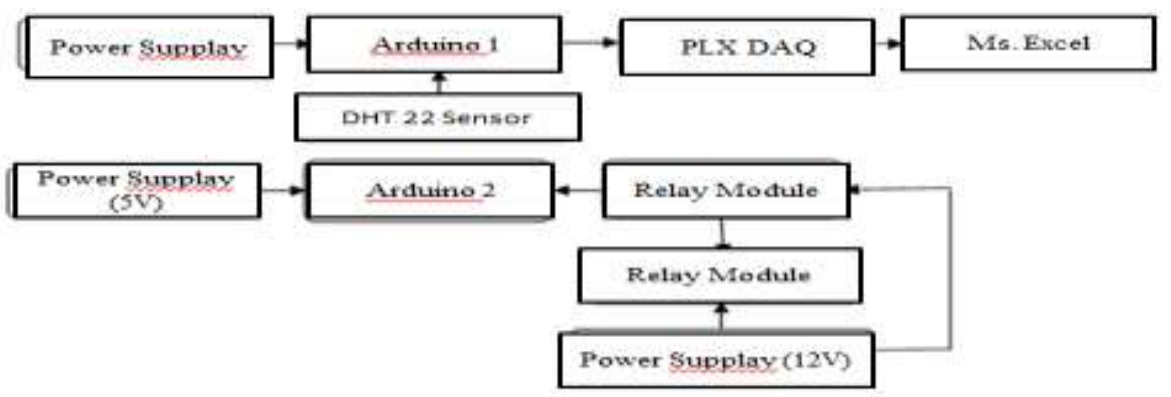

Figure 1. Block Diagram of The System

In this research, the experiment was conducted by using Arduino nano microcontroller as an object that will be studied dissipation of electrical energy into heat energy when standby for 5 minutes and this tool can operate for 55 minutes, this is explained in Figure 2.

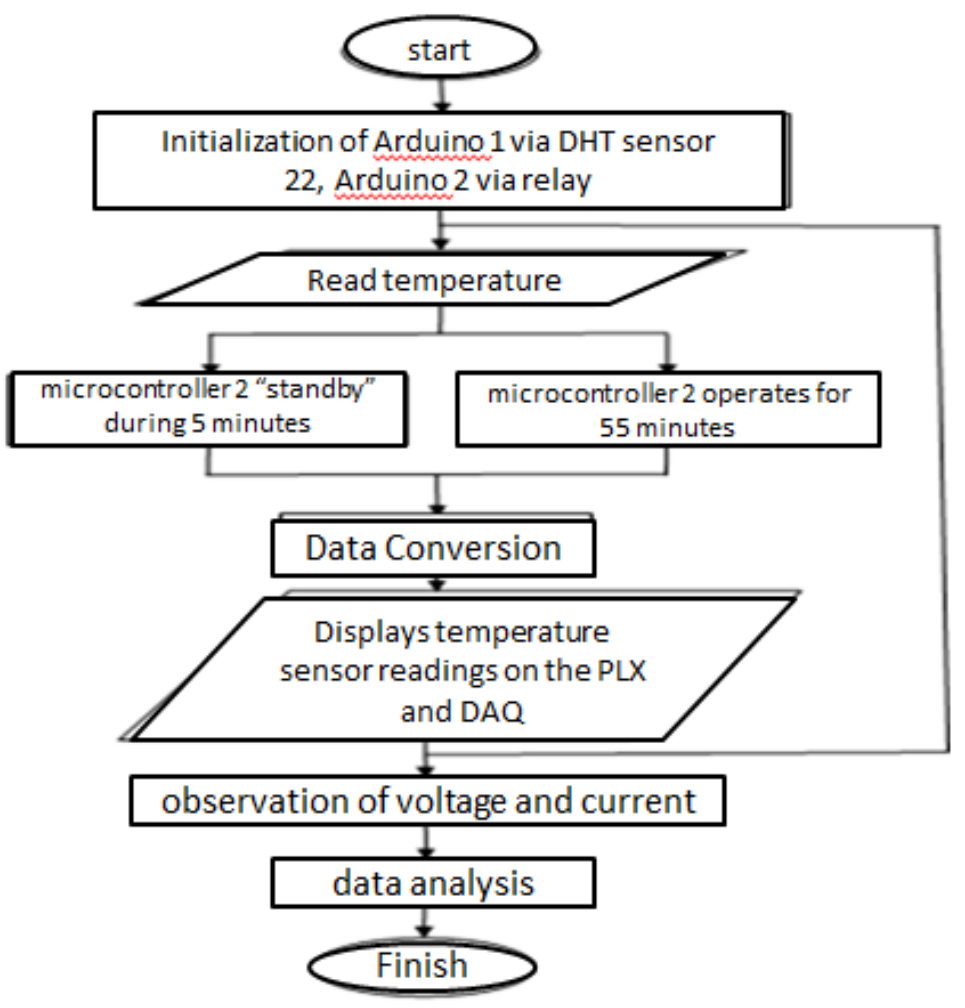

Figure 2. Research Flowchart

Arduino Nano is a small microcontroller development board based on the ATMega328 microcontroller [16]. Arduino Nano microcontroller testing is used to see changes in temperature, voltage, and current. Temperature changes are displayed in PLX-DAQ in Excel form which can then be processed for graphic form analysis [17]. Temperature changes are used to obtain heat energy values. Voltage in the form of Volt output by parallel method and current in the form of Ampere output with series method measured using multimeter [18]. Then the result of voltage and current changes are used to get the value of electrical energy. Calculation of the percentage value of the dissipation of electrical energy into heat energy in microcontrollers can be known by using equation 1 as the calculation of electrical energy, while 
equation 2 as the calculation of heat energy, and equation 3 as the calculation of the percentage of dissipation of electrical energy into heat energy [19].

$$
\begin{aligned}
& E=V . I . t \\
& Q=m . c . \Delta T \\
& \%=\frac{Q}{E} \times 100 \%
\end{aligned}
$$

Description:

$$
\begin{aligned}
& \mathrm{V}=\text { Voltage }(\text { Volt }) \\
& \mathrm{I}=\text { Current }(\text { Ampere }) \\
& \mathrm{t}=\text { timing (detik) } \\
& \mathrm{m}=\text { microcontroller mass }(\mathrm{Kg}) \\
& \mathrm{c}=\text { Specific heat }\left(\mathrm{J} / \mathrm{Kg}{ }^{\circ} \mathrm{C}\right) \\
& \Delta \mathrm{T}=\text { Temperature changes }\left({ }^{\circ} \mathrm{C}\right)
\end{aligned}
$$

\section{Result and Discussion}

This research was conducted to analyze the percentage of dissipation of electric energy to heat energy on a microcontroller from standby to stable operation and to find out when the dissipation of electrical energy into heat energy is stable during operation. This can be seen based on changes in temperature, voltage, and current with time.

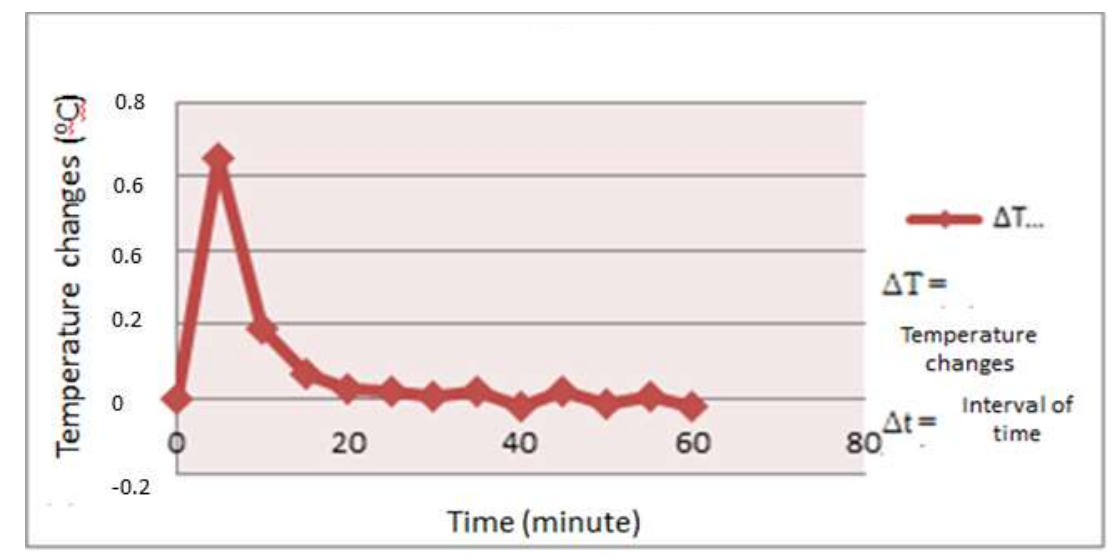

Figure 3. Graph of average temperature changes to time

Figure 3 shows that at standby at $0-5$ minutes the temperature change of $0.65^{\circ} \mathrm{C}$ is relatively higher than when the microcontroller was operating. At the time of operation, the temperature change is lower and stable which is $0.02^{\circ} \mathrm{C}$ because the microcontroller can release heat so that the energy absorbed by the ambient is the same. The (-) sign of the temperature change is a decrease in the temperature from a stable state. 


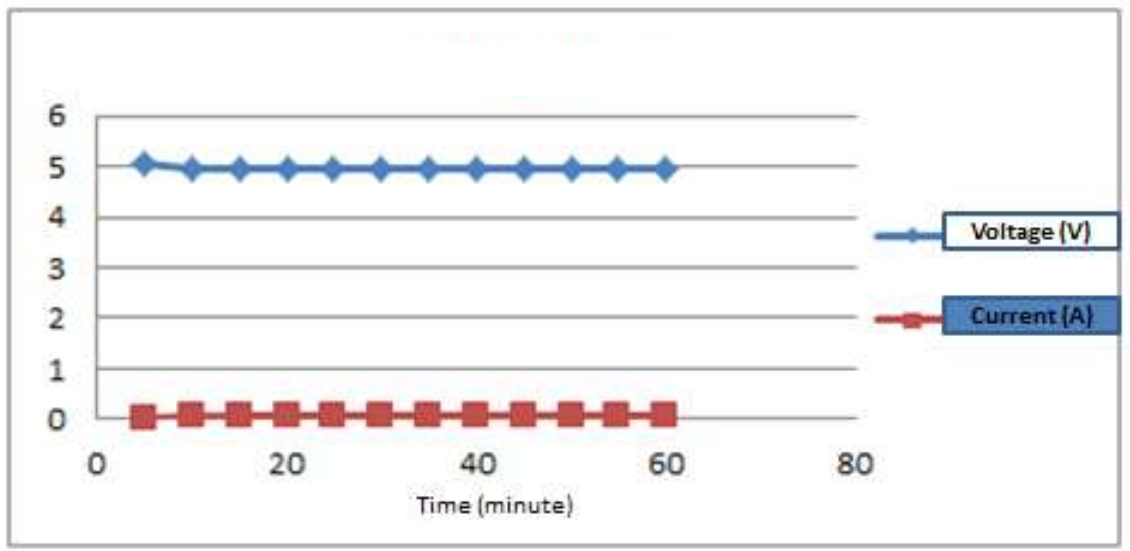

Figure 4. Changes in voltage and current over time

Measurement of microcontroller voltage by parallelly connecting multimeter positive cable with VCC microcontroller and negative cable multimeter with GND microcontroller can be done to measure microcontroller current by connecting serial positive cable multimeter with $5 \mathrm{~V}$ adapter and negative cable multimeter with VCC microcontroller. Figure 4 shows that the voltage decreases steadily and the current increases steadily.

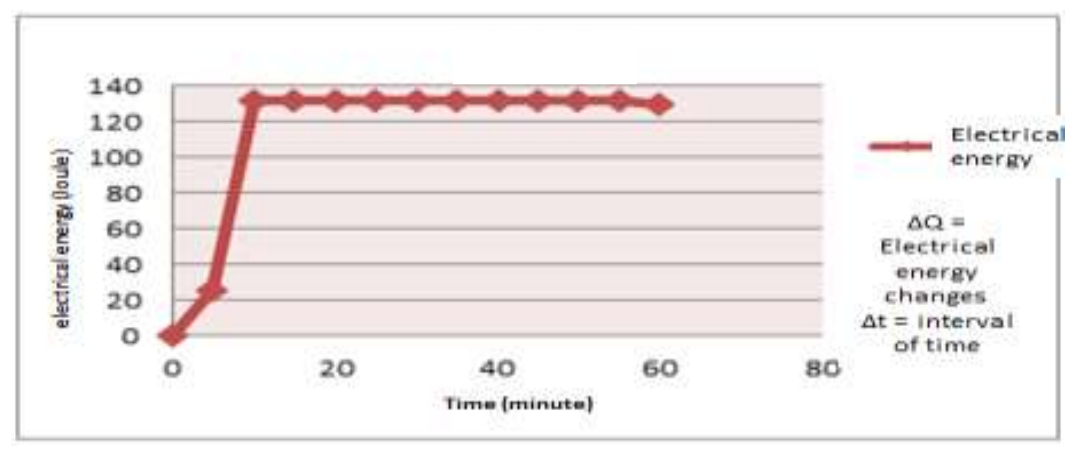

Figure 5. electrical energy calculation results

Figure 5 shows the increase in electrical energy to a stable state. At the interval of 0-5 minutes produces electrical energy of 25.755 Joules in the standby position that is microcontroller is not given a load, at a time interval of 5-10 minutes there is an increase in electrical energy to 131.684 Joule. This happens because the microcontroller is already connected to the load resulting in a larger current to run the relay module which affects the amount of electrical energy. Furthermore, electrical energy is relatively stable despite the decrease in electrical energy. Factors that cause uncertainty in measurement are Human error, measuring instruments, etc [20]. 


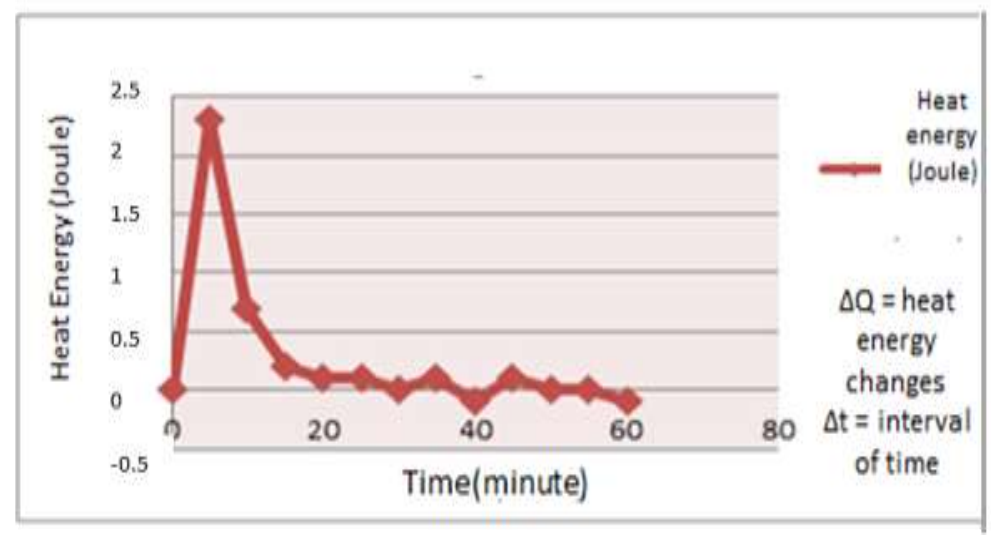

Figure 6. Results of heat energy calculation

Electrical energy can turn into heat energy in four stages, namely standby, end standby to operate, transitional state, and stability. Figure 6 shows the increase in heat energy to an ideal stable state. At intervals of 0-5 minutes produce heat energy of 2.3 Joules are on standby and at intervals of 5-10 minutes produce heat energy that is 0.7 Joule is at the end of standby until operation. Electrical energy does not fully heat up because it is used to operate the microcontroller against the relay as a load to turn on the pump so that the temperature rise when operating is smaller than when standby affects heat energy. Furthermore, heat energy is relatively stable because the heat energy of microcontrollers and energy absorbed by ambient is the same despite the decrease in heat energy. A sign of negative value in heat energy indicates a decrease in heat energy from an ideal stable state of heat energy.

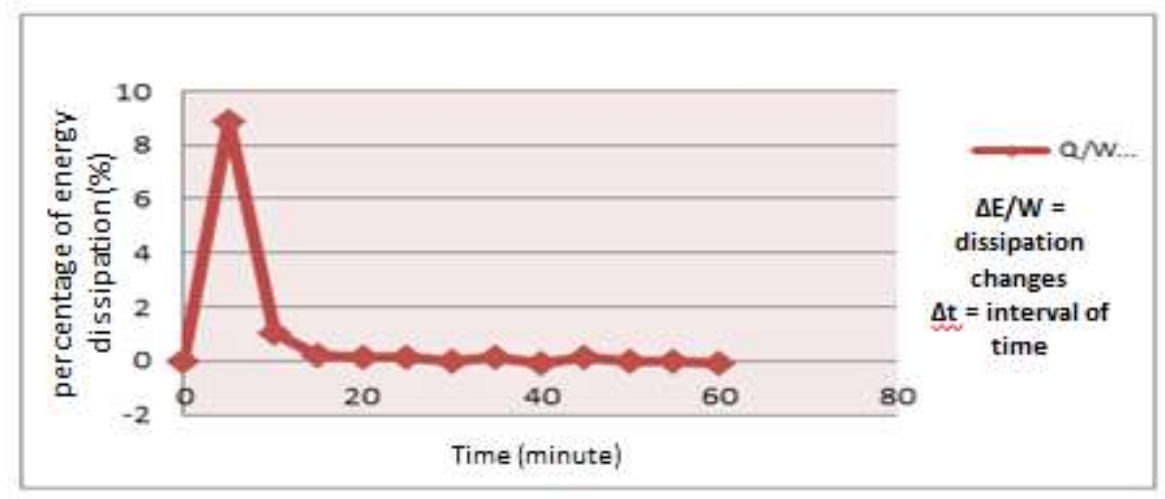

Figure 7. Calculation of the percentage of dissipation of electrical energy into heat energy

Figure 7 shows that the percentage of energy dissipation in standby increased by $8.9 \%$, at the end of standby until operating $1.0 \%$, in a transitional state of $0.2 \%$, and stable state of $0.1 \%$ $0 \%$. 


\section{Conclusion}

The percentage of electricity dissipation into heat energy on standby state from 0 to 5 minutes increased by $8.9 \%$. After the dissipation of electrical energy is connected with a series of pumps at a time of 5-10 minutes there is a dissipation of $1 \%$. This situation is smaller than the previous state until it becomes stable. The dissipation of electrical energy into heat energy can be stable when the microcontroller is operating after 20 minutes to 60 minutes or finishes operating.

\section{REFERENCES}

[1] T. A. Wiranata, "Persepsi Masyarakat dalam Penerapan Rumah Hemat Energi. Jurnal Lingkungan Binaan Indonesia", Jurnal Lingkungan Binaan Indonesia, vol. 6, no. 1, pp.2832, 2017.

[2] M. S. Fadliah, "Pemanasan Global, Faktor Penyebab, Dampak dan Solusi", Jurnal Pelangi Ilmu, vol.1, no.1, 2008.

[3] A. J. White, "Loss analysis of thermal reservoirs for electrical energy storage schemes", Applied Energy, vol. 88, no.11, pp.4150-4159, 2011.

[4] A. Sumper and A. Baggini, Electrical energy efficiency: technologies and applications. John Wiley \& Sons, 2012.

[5] H. A. Dharmawan, Mikrokontroler Konsep Dasar dan Praktik, Malang: UBMedia, 2017.

[6] N. L. Tirtasari, "Uji kalibrasi (ketidakpastian pengukuran) neraca analitik di laboratorium biologi FMIPA UNNES”, Indonesian Journal of Chemical Science, vol. 6, no. 2, pp.151$155,2017$.

[7] S. Wijonarko, T. Maftukhah, D. Rustandi, B. Sirenden, and N. T. Darmayanti, "Web based rain gauge calibrator", Instrumentasi, vol. 43, no. 1, pp.25-42, 2019.

[8] A. Parastiwi, C. Rahmad and A. N. Rahmanto, Pemrogaman Spreadsheet Untuk Pemodelan Kontrol Rangkaian Elektronika (Vol. 1). UPT Percetakan dan Penerbitan Polinema, 2018.

[9] L. E. Maryanto, B. Basyirun, and S. Anis, "Pengaruh Diameter Roller Terhadap Debit Pompa Peristaltik", Sainteknol: Jurnal Sains dan Teknologi, vol. 16, no. 1, pp.65-72, 2018.

[10] I. A. B. Andhika, Monitoring Suhu Pemanas Portable Berbasis Arduino Yang Terintegrasi Dengan Android, Doctoral dissertation, Universitas Muhammdaiyah Surakarta, 2017.

[11] A. K. Tsauqi, M. Hadijaya, I. Manuel, V. M. Hasan, A. Tsalsabila, F. Chandra, T. Yuliana, P. Tarigan, and I. Irzaman, "Saklar Otomatis Berbasis Light Dependent Resistor (Ldr) Pada Mikrokontroler Arduino Uno" In Prosiding Seminar Nasional Fisika (E-Journal), vol. 5, pp. SNF2016-CIP, 2016, October.

[12] Junaidi, Project Sistem Kendali Elektronik Berbasis Arduino, Lampung: AURA, 2018.

[13] D. Nedelkovski, DHT11 \& DHT22 Sensors Temperature and Humidity Tutorial using Arduino, 2016. Available from http://howtomechatronics. com/tutorials/arduino/dht11dht22-sensors-temperature-and-humidity-tutorial-using-arduino/[Accessed: Februari 15, 2018].

[14] G. J. Pagar, and B. V. Varade, "An Overview of Vibrational Analysis of Peristaltic Pump", International Journal Of Recent Trends In Engineering And Research, vol. 2 , no.12, 2016.

[15] A. Nuryaman, E. Mulyana, and R. Mardiati, "Rancang Bangun Prototipe Alat Pengukur Kecepatan Kendaraan Dengan Sensor Infra Merah", In Prosiding-Seminar Nasional Teknik Elektro UIN Sunan Gunung Djati Bandung, pp. 345-366, 2018, January.

[16] Waluyo, B. Dwi, and K. Simanjuntak, "Pengembangan Trainer Mikrokontroler Berbasis Arduino Nano Pada Mata Pelajaran Teknik Pemrograman, Mikroprosesor dan Mikrokontroler Kelas XI Kompetensi Keahlian Teknik Audio Video di SMKN 1 Lubuk Pakam." Jurnal Teknologi Informasi \& Komunikasi Dalam Pendidikan, vol. 7, no. 1, pp: 17, 2020. 
[17] M. R. Fachri, I. D. Sara, and Y. Away, "Pemantauan parameter panel surya berbasis arduino secara real time", Jurnal Rekayasa Elektrika, vol. 11, no. 4, pp.123-128, 2015.

[18] U. Wahyudi, Mahir dan Terampil Belajar Elektronika Untuk Pemula, Deepublish, 2018.

[19] H. Kunlestiowati, "Analisis penyimpangan konversi energi listrik menjadi kalor pada perangkat eksperimen Hukum Joule", Jurnal Riset dan Kajian Pendidikan Fisika, vol. 5, no.1, pp.34-39, 2018.

[20] P. Pandiangan and A. Arkundato, Ketidakpastian dan Pengukuran. MODUL 1: KETIDAKPASTIAN DAN PENGUKURAN 1.1, Universitas Terbuka, 2018. 